\title{
The use of ceftriaxone impregnated beads in the management of chronic osteomyelitis
}

\author{
Andri MT Lubis, S Dohar L Tobing, Paruhum U Siregar
}

\begin{abstract}
Abstrak
Saat ini penanganan osteomielitis kronis masih merupakan masalah dalam bidang orthopaedi. Debridemen dan pemberian antibiotika merupakan penatalaksanaan yang dianut. Seringkali antibiotika yang diberikan secara oral maupun parenteral tidak dapat mencapai lokasi infeksi dengan baik. Para ahli mengembangkan pemberian antibiotika lokal dalam bentuk antibiotic beads. Antibiotic beads yang terdapat dipasaran saat ini sangat mahal, sehingga kami mencoba membuat antibiotic beads sendiri dengan menggunakan bahan aktif ceftriakson. Ceftriaxone impregnated beads dibuat dengan mencampur 2 gram bubuk ceftriakson dan 40 gram polimetilmetakrilat secara steril. Ukuran beads $3 \times 5 \mathrm{~mm}$. Digunakan 30 ekor kelinci jantan yang masing-masing dilakukan induksi osteomielitis pada tulang radius kirinya dengan menggunakan kuman Staphylococcus aureus. Pada minggu ke-4 dilakukan pemeriksaan klinis, radiologis, biakan kuman dan histopatologis untuk membuktikan adanya osteomielitis. Selanjutnya dibagi menjadi tiga kelompok dengan jumlah setiap kelompoknya sepuluh kelinci. Kelompok pertama hanya dilakukan debridemen. Kelompok kedua debridemen diikuti pemberian ceftriakson intravena. Kelompok ke-3 debridemen diikuti pemberian ceftriakson intravena dan ceftriaxone impregnated beads. Setelah empat minggu kembali dievaluasi secara klinis, radiologis, biakan kuman dan histopatologis. Pada kelompok pertama, kejadian osteomielitis pada akhir empat minggu terapi adalah 60\% (angka keberhasilan 40\%). Pada kelompok kedua, angka kejadian osteomielitis setelah pengobatan adalah 20\% (angka keberhasilan 80\%). Sedangkan kejadian osteomielitis setelah empat minggu pengobatan pada kelompok ketiga adalah 0\% (angka keberhasilan 100\%). Kesimpulan: kombinasi antibiotik sistemik dengan ceftriaxone impregnated beads lebih efektif dari antibiotik sistemik. (Med J Indones 2005; 14: 157-62)
\end{abstract}

\begin{abstract}
Up to now, orthopaedic management of chronic osteomyelitis is still problematic. Debridement and antibiotic administration is still a widely practiced management. However, oral or parenteral antibiotics often cannot reach the infection site well. Some experts have developed a system to administer local antibiotic in the form of antibiotic beads. Antibiotic beads on the market are still very expensive. Therefore, we made efforts to make our own antibiotic beads by using Ceftriaxone as the antibiotic. Ceftriaxone impregnated beads were made by mixing 2 grams of Ceftriaxone powder with 40 grams of polymethyl methacrylate (PMMA) bone cement sterilely. The size of the beads was $3 \times 5 \mathrm{~mm}$. Thirty male rabbits that were induced to get osteomyelitis by inoculating Staphylococcus aureus to their left radius bones were used. In the fourth week, clinical, radiological, histological examination and bacterial culture were performed to prove the presence of osteomyelitis. Then, the samples were divided into 3 groups of ten. The first group only underwent debridement. The second group underwent debridement followed by intravenous Ceftriaxone administration. The third group underwent debridement followed by intravenous Ceftriaxone and Ceftriaxone-impregnated beads administration. After four weeks, clinical, radiological, histological examination and bacterial culture were repeated. In the first group, the incidence rate of osteomyelitis at the end of the fourth week of therapy was 60\% (success rate 40\%). In the second group, after four weeks of therapy the incidence rate of osteomyelitis after treatment was 20\% (success rate $80 \%$ ), whereas that of the third group was $0 \%$ (success rate 100\%). In conclusion, the efficacy of combination of systemic antibiotic therapy and ceftriaxone impregnated beads in the therapy of chronic osteomyelitis is better than systemic antibiotic therapy. (Med J Indones 2005; 14: 157-62)
\end{abstract}

Keywords: debridement, polymethyl methacrylate

The presence of a barrier between the body's immune system and infection focus could complicate the

Department of Orthopaedic and Traumatology, Faculty of Medicine, University of Indonesia / Cipto Mangunkusumo Hospital, Jakarta, Indonesia management of osteomyelitis. The infection focus in a bone is often sheathed by an avascularized sclerotic bone, and Haversian canals are often occluded by scars and protein material. Besides thickening, some part of the periosteum becomes a sclerotic tissue together with the adjacent muscles and subcutaneous tissue. ${ }^{1-3}$ That is the reason why the infection focus 
becomes relatively avascularized and can not be adequately reached by systemic antibiotics.

The difficulty of systemic antibiotics to reach the infection focus based the idea of administering local antibiotics. The disadvantage becomes beneficial in administering local antibiotics, because blood-bone barrier localizes the antibiotic concentration in the infection area, so that systemic concentration is low, in some cases, it can not even be detected. In this way, the patient can be prevented from the risk of antibiotic toxicity. ${ }^{4,5}$

The brand name of standard antibiotic beads is Septopal ${ }^{\circledR}$ (Merck, Darmstadt, Germany). It was commercially available for the first time in $1976 .^{6-9}$ Gentamycin is the antibiotic mostly used because of the following nature: in low doses it is active against gram-positive and negative bacteria, it is hypoallergenic, watersoluble, stable in high temperatures and has a relatively low resistance rate. ${ }^{10}$ In an in vitro study, Mader et al found that polymethyl methacrylate (PMMA) impregnated with tobramycin and clyndamycin gave a concentration above minimal inhibitory concentration for more than 90 days. ${ }^{11}$ Another study revealed that 70 days following implantation, gentamycin concentration was still in therapeutic level in the connective tissue around the beads. ${ }^{12}$

Commercial antibiotic beads such as gentamycin beads are available on the market, but the prices are very high so that the use in developing countries is still limited. In studies conducted abroad, Ceftriaxone polymethylmethacrylate, could, in fact, be produced locally with a very competitive price. ${ }^{13}$

Antibiotic beads offer some advantages compared with systemic antibiotics, especially in their ability to deliver high-dose antibiotics directly to the infection focus, and spare the patients from allergic reaction or the possibility of exposures to ototoxic and nephrotoxic doses. ${ }^{3}$

A latest study revealed the emergence of bacteria that were resistant to gentamycin, so that the routine use of antibiotic beads requires reconsideration. ${ }^{14}$ In this case, the prescription of ceftriaxone beads could be a solution.

The use of antibiotic beads provides high antibiotic concentration for a long time, gives comfort in wound care, and makes flexible schedules for reconstruction of dead space. ${ }^{15,16}$ Moreover, a number of in vivo trials using antibiotic beads gave the same results and efficacy compared to long-term systemic antibiotics. ${ }^{12,17-21}$

In this study, we used ceftriaxone beads, as they can be made with a reasonable price. Ceftriaxone is the third generation of parenteral semi-synthetic cephalosporin with a relatively long half-life. Ceftriaxone works to eradicate gram-negative, gram-positive and anaerobic bacteria. ${ }^{13}$

\section{METHODS}

In this study home-made ceftriaxone impregnated beads were used. The ceftriaxone beads were made in sterile condition, by mixing 2 grams of ceftriaxone powder with 40 grams of PMMA bone cement (CME 3 De Puy Johnson and Johnson). Ceftriaxone-PMMA beads were molded in our home-made moulds that can produce beads of $7 \times 5 \mathrm{~mm}$ and $3 \times 5 \mathrm{~mm}$. In this study, the $3 \times 5 \mathrm{~mm}$ beads were used.

Thirty male New Zealand and local Indonesian (West Java) crossbred rabbits were selected with body weights ranging from 2500 to 3000 grams. Anesthesia was conducted by general anesthesia using ketalar and intravenous diazepam. The whole procedures were performed according to an aseptic and antiseptic procedure. In the initial phase of the trial, osteomyelitis was induced on the left radius bone of each rabbit. Osteomyelitis was induced by performing osteotomy, taking $1 \mathrm{~cm}$ of the bone and inoculating them with $0.9 \times 10^{9}$ (Mc Farland 3) of Staphylococcus aureus (American type culture collection number 6538), followed by insertion of the bone fragments back into the wound. All of the wounds were sutured with silk threads 4-0. Following the operation, each rabbit was isolated in a separate cage and weight bearing was allowed on the intact ulna. The rabbits were fed with the same food and evaluated clinically by assessing the wound condition, and measuring the body weights.

The presence of osteomyelitis was based on the results of clinical (Figure 1), radiological (in the forms of osteolysis, sequestration, involucrum formation and radius sclerosis) (Figure 2), culture and histopathological examination. Specimen for culture and histopathological examinations were taken during debridement. The rabbits were divided into 3 groups of 10 randomly, and at the end of the fourth week were treated as the following: 


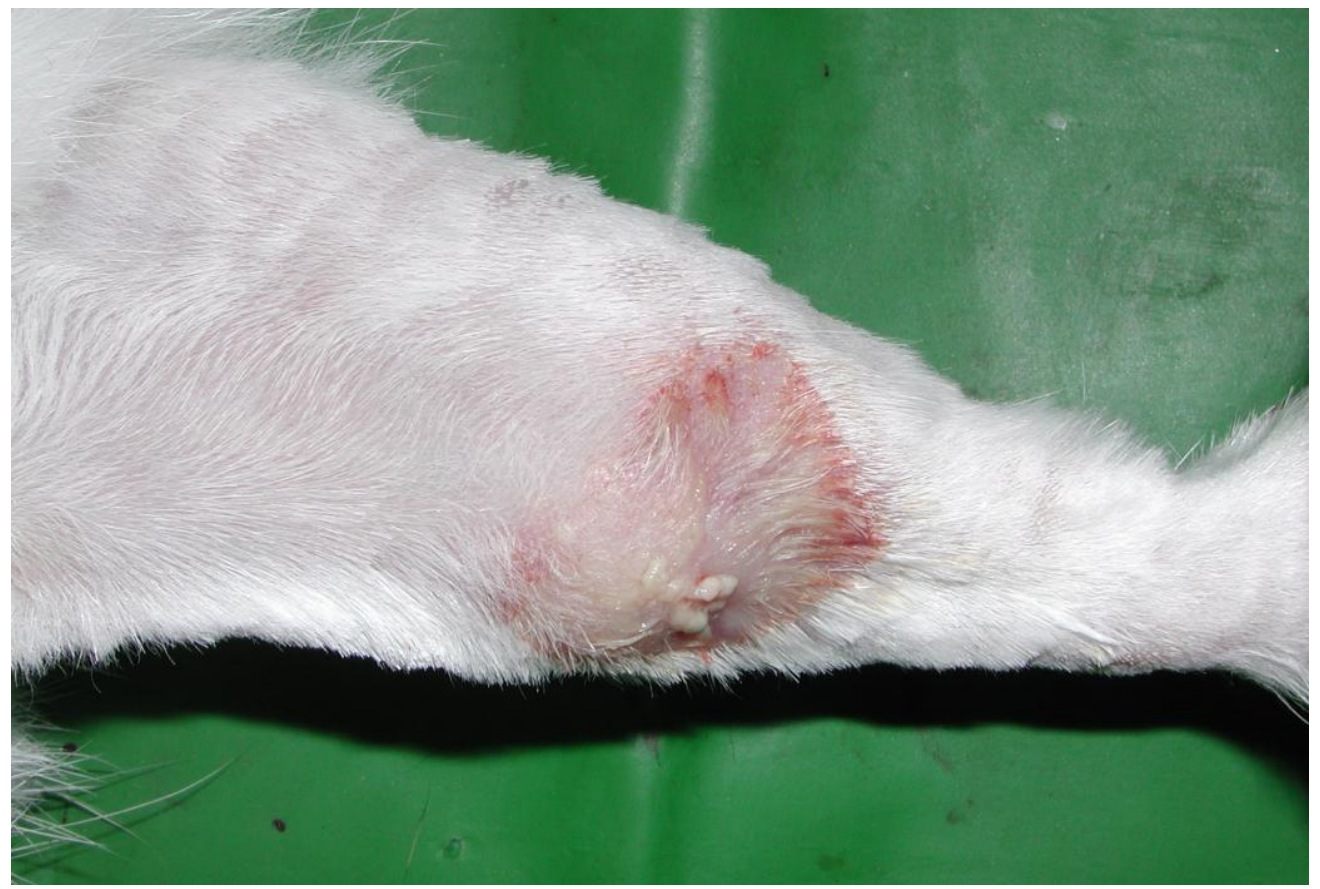

Figure 1. Clinical appearance of one of the samples' limb with osteomyelitis. An inflammation and a fistula were found

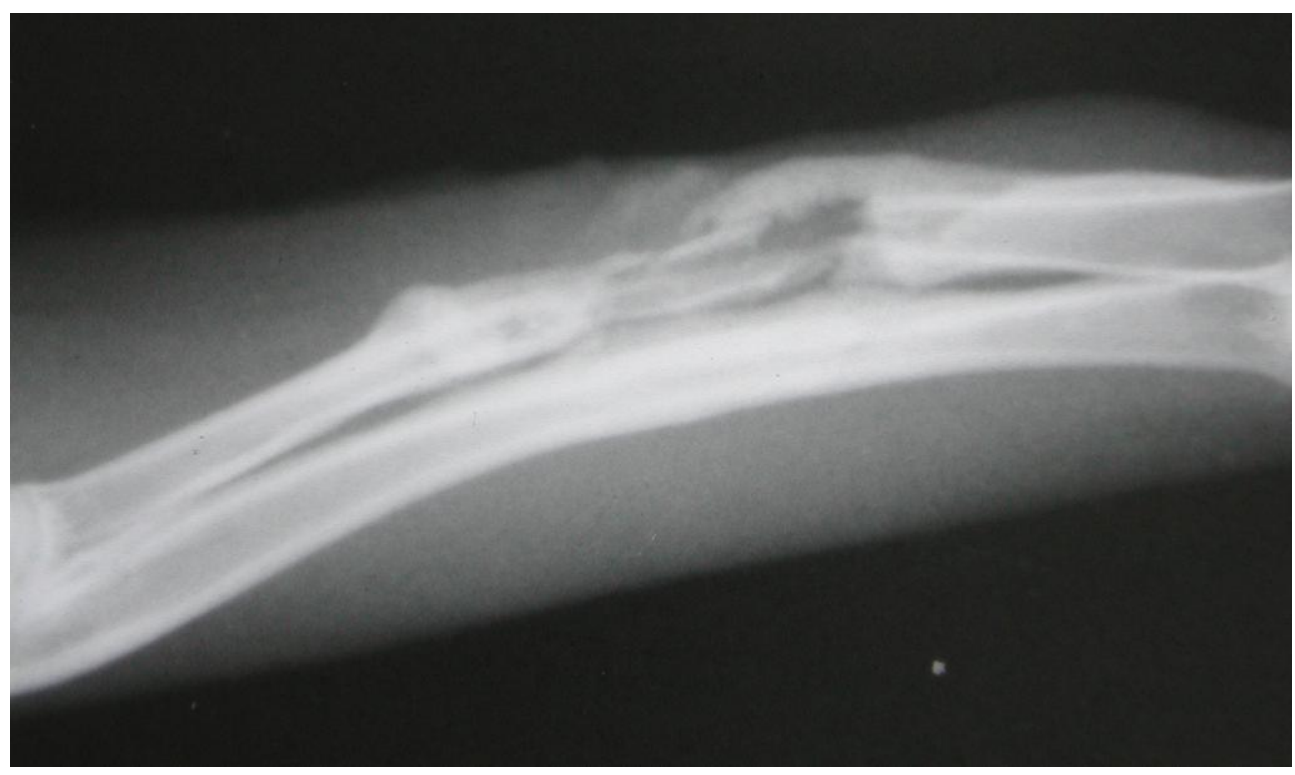

Figure 2. X ray of one of the samples' left radius with osteomyelitis. Osteomyelitis appearance including osteolysis, sclerosis, involucrum and sequestrum formation was found 
Group I : debridement only

Group II : debridement followed with intravenous generic ceftriaxone injections (Indopharma) with the dose of $25 \mathrm{mg}$ twice daily for 4 weeks.

Group III : debridement followed with intravenous generic ceftriaxone injections (Indopharma) with the dose of $25 \mathrm{mg}$ twice daily, and implantation of ceftriaxone impregnated beads for 4 weeks.

All debridements of necrotic tissue (necrotic bone as well as infected soft tissue) were performed after signs of osteomyelitis were found on radiological examination.

Ceftriaxone was selected as the antibiotics for the systemic management due to its practicality and efficacy to eradicate Staphylococcus aureus. Ceftriaxone is a cephalosporin which is an effective antibiotic for the treatment of osteomyelitis.

After debridement all of the wounds were sutured and examined daily. Four weeks after treatment (in the eighth week), evaluation by clinical examination was carried out. The rabbits were then sacrificed and radiological, culture and histopathological examinations were done. For culture and histopathological examinations, the lower limb (radius and ulna bones) were excised intact. The patterns of wound were noted, and a culture of the specimen taken from the wound was done. The left lower limbs were fixed in a $10 \%$ formalin solution. Then, the specimen was blocked in paraffin and sliced in $6 \mu \mathrm{m}$ coronal incisions using a microtome. Staining was performed with eosin hematoxyline and Gram staining, and microscopic examination was performed.

Osteomyelitis was identified by culture and histopathological results that revealed the presence of gram-positive intraosseus coccus and polymorphonuclear (PMN) leucocytes.
A wound was regarded as infected if an erythematous region, oedema, abscess and occasionally a fistula was found on the lower limb.

\section{Statistical analysis}

Kruskal-Wallis test was used to compare the results of the management in the three groups. Mann-Whitney test was used to compare the results of the management in the two groups.

\section{RESULTS}

Infected wounds generally appeared in the fourth week after the failure of treatment.

Four weeks after germ inoculation, all of the rabbits showed signs of osteomyelitis clinically, radiologically and in culture with the presence of Staphylococcus aureus. The histopathological change as an indicator for osteomyelitis was identified in all rabbits during debridement, and in cases which failed to respond to the therapy, four weeks later.

Kruskal-Wallis test showed a significant difference $(\mathrm{p}<0.05)$ beween the 3 groups. A significant difference was found beween the first group and the third group (results of the osteomyelitis therapy in the third group were better than those of the first group). However, a significant difference was not found between the second and third group, though a tendency for better results was found in the third group compared to the second group.

In the first group, the incidence rate of osteomyelitis at the end of the four weeks' therapy was $60 \%$ (success rate 40\%). In the second group, the incidence rate of osteomyelitis after therapy was $20 \%$ (success rate $80 \%$ ) whereas the incidence rate of osteomyelitis after four weeks' therapy in the third group was $0 \%$ (success rate 100\%) (Figure 3). 


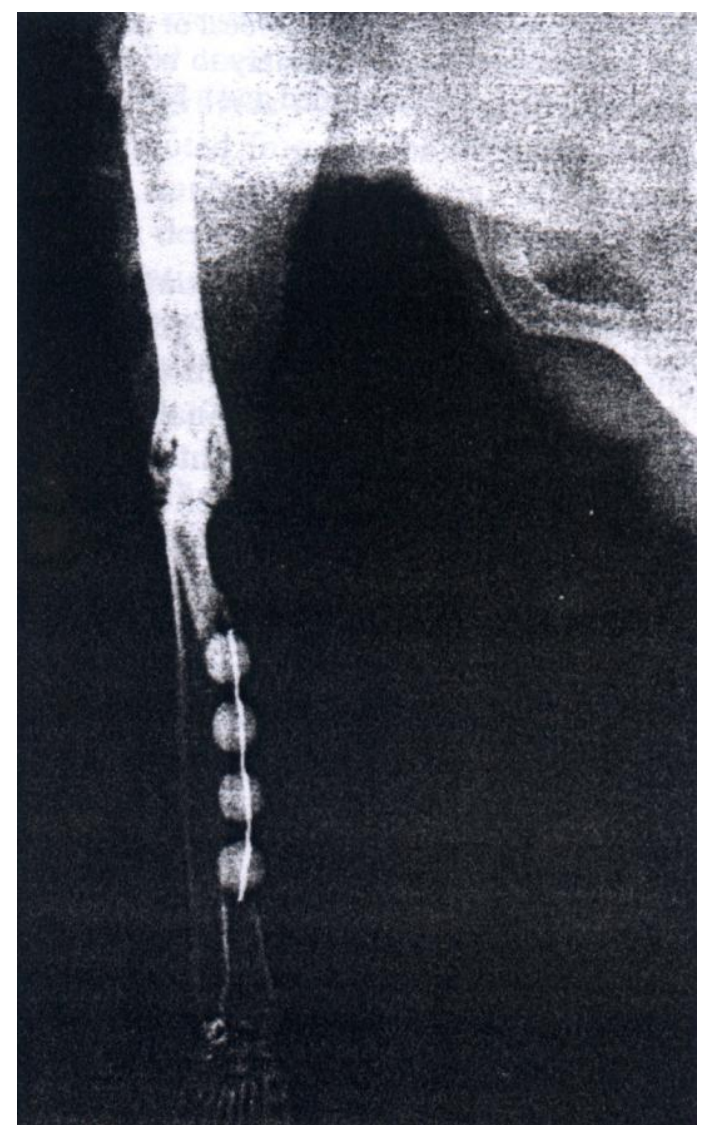

Figure 3. X ray of one of the samples' left radius with the application of ceftriaxone impregnated beads. There were no signs of osteomyelitis.

\section{DISCUSSION}

This was a prospective study and was set up to compare the efficacy of combination of systemic antibiotic and ceftriaxone impregnated beads in chronic osteomyelitis management compared with the conventional long-term antibiotic management.

Theoretically one of the advantages of the use of ceftriaxone impregnated beads is the release of highdose ceftriaxone at the infection site and wound environment. Diffusion of this antibiotic does not depend on vascularization and condition of the soft tissue. Systemic antibiotics can reach the infection focus, but their concentration depends on local condition and vascularization. Furthermore, the concentration tends to be lower compared with the concentration released by antibiotic impregnated beads. Besides that, the use of antibiotic impregnated beads does not depend on patient's compliance, and could reduce toxicity, cost and discomfort related to the use of systemic antibiotics. At least, antibiotic impregnated beads can increase the success rate of treatment if used as an adjuvant therapy to the systemic antibiotic treatment and can provide dead-space therapeutic management in the reconstructive step. ${ }^{19}$

One of the disadvantages of ceftriaxone impregnated beads is the limited use, only for bacterias that are sensitive to ceftriaxone. In spite of the controversy, the removal of ceftriaxone impregnated beads is recommended at the end of the treatment (6 weeks). In this case, additional procedures are needed. However, it will not be a problem if reconstructive surgery is required at the end of the antibiotic therapy.

Our data revealed that combination of ceftriaxone impregnated beads and systemic antibiotic could significantly increase the success rate of the therapy, compared with debridement only.

Even though there was no significant difference in the success rate between the systemic antibiotic therapy and the combination of systemic antibiotic and ceftriaxone impregnated beads therapy, the combination therapy yielded a $100 \%$ success rate.

In conclusion, the efficacy of combination of systemic antibiotic therapy and ceftriaxone impregnated beads in the therapy of chronic osteomyelitis is better than systemic antibiotic therapy. Cost might be cheaper if the impregnated ceftriaxone beads could be produced in large quality.

\section{REFERENCES}

1. Sochen JE. Orthopedics wounds. Am J Surg 1994; Suppl 1A 167:53-5.

2. Kanellakopoulou K, Giamarellos EJ. Carrier system for the local delivery of antibiotics in bone infections. Drugs 2000; 59 (6):1223-32.

3. Henry SL, Hood GA, Seligson D. Long-term implantation of gentamycin-polymethylmetacrylate antibiotics beads. Clin Orthop 1993;295:47-53.

4. Ciampolini J, Harding KG. Pathophysiology of chronic bacterial osteomyelitis. Why do antibiotics fail so often? Postgrad Med J 2000; 76:479-83.

5. Walenkamp GHIM, Vree TB, Van Rens TJG. GentamicinPMMA beads: Pharmacokinetic and nephrotoxicological study. Clin Orthop 1986; 205:171-82.

6. Blaha JD, Calhoun JH, Nelson CL, Henry SL, Seligson D, Esterhai JL, et al. Comparison of the clinical efficacy and tolerance of Gentamicin PMMA beads on surgical wire 
versus combined and systemic therapy for osteomielitis. Clin Orthop 1993; 295:8-12.

7. Van Sorge N, Yska JP, Blansjaar H, Driessen S, Schepers P:, Bovenga SR et al. Gentamicin Containing Surgical bone cement: in vitro elution characteristics of Palacos and Palamed. In $6^{\text {th }}$ Internet World Congress for Biomedical Sciences Jan $11^{\text {th }}$ 2000. Available from: URL: http://www.uclm.es/inabis2000/posters/files/067/session.htm

8. Flick AB, Herbert JC, Goodell J, Kristiansen T. Noncommercial Fabrication of Antibiotic-impregnated polymethylmethacrylate beads. Clin Orthop 1987; 223:282-6.

9. Nelson CL, Griffin FM, Harrison BH, Cooper RE. In vitro elution characteristics of commercially and noncommercially prepared antibiotic PMMA beads. Clin Orthop 1992; 284:303-9.

10. Wahlig H, Dingeldein E, Bergmann R, Reuss K. The release of gentamycin from polymethylmetacrylate beads. J Bone Joint Surg 1978; 60B(2): 270-5.

11. Mader JT, Calhoun J, Cobos J. In vitro evaluation of antibiotics diffusion from antibiotic-impregnated biodegradable beads and polymethylmethacrylate beads. Antimicrob Agents Chemother 1997; 41(2):415-18.

12. Majid SA, Linberg LT, Gutenberg B, Siddiki MS. Gentamicin-PMMA beads in the treatment of chronic osteomyelitis. Acta Orthop Scand 1985 ; 56:265-268.

13. Alonge TO, Fashina AN. Ceftriaxone-PMMA beads - A slow release preparation? Int J Clin Pract 2000; 54(6): 353-5.

14. Tunney MM, Ramage G, Patrick S, Nixon JR, Murphy PG,Gorman SP. Antimicrobial susceptibility of bacteria isolated from orthopedic implants following revision hip surgery. Antimicrob Agents Chemother 1998; 42(11): 3002-5.

15. Haydon RC, Blaha JD, Mancinelli C, Koike K. Audiometric thresholds in osteomyelitis patients treated with gentamycin - impregnated methylmethacrylate beads (Septopal). Clin Orthop 1993; 295:43-6.

16. Ueng SWN, Wei FC, Shih CH. Management of large infected tibial defects with antibiotic beads local therapy and staged fibular osteoseptocutaneous free transfer. J Trauma 1997; 43(2):268-274.

17. Calhoun JH, Anger DM, Ledbetter BR, Cobos JA, Mader JT. The Ilizarov Fixator and polymethylmetacrylateantibiotics beads for the treatment of infected deformities. Clin Orthop 1993; 295:13-22.

18. Classen DA. Antibiotic bead pouch dressing. Available from URL : http://www.pulsus.com/PLASTICS/04_04/clas_ed.htm.

19. Evans RP, Nelson CL. Gentamicin impregnated polymethylmetacrylate beads compared with systemic antibiotic therapy in the treatment of chronic osteomyelitis. Clin Orthop 1993; 295:37-42.

20. Kluechle DK, Landon GC, Musher DM, Noble PC. Elution of vancomycin, daptomycin, and amikacin from acrylic bone cement. Clin orthop 1991; 264:302-8.

21. Henry SL, Ostermann PA, Seligson D. The prophylactic use of antibiotic impregnated beads in open fracture. J Trauma 1990; 30(10):1231-8. 